\title{
Minat Belajar Siswa Dalam Mempraktekan Pembelajaran Penjas Di Rumah Pada Masa Covid-19
}

\section{Student Interest in Practicing Physical Education at Home During the Covid- 19 Period}

\author{
Bela Nugraha, Akhmad Dimyati, Resty Gustiawati \\ Pendidikan Jasmani Keolahragaan dan Rekreasi, Fakultas Pendidikan dan Ilmu Pendidikan, \\ Universitas Singaperbangsa Karawang, Jl. HS.Ronggo Waluyo, Puseurjaya, Kec. Telukjambe Tim, Kabupaten \\ Karawang, Jawa Barat, 41361, Indonesia \\ e-mail : bellanugraha3@gmail.com. akhmad.dimyati@fkip.unsika.ac.id. restygustiawati@fkip.unsika.ac.id
}

\begin{abstract}
Abstrak
Tujuan dari penelitian ini dilakukan untuk mengetahui minat belajar siswa dalam mempraktekan pembelajaran penjas di rumah di Masa Pandemic Covid-19 Kelas X di SMAN 1 PASAWAHAN. Untuk menjawab rumusan masalah penelitian yang telah dirumuskan, penulis menggunakan pendekatan kuantitatif dengan metode survey. Penelitian ini dilakukan di SMAN 1 PASAWAHAN dengan mengambil seluruh kelas $X$ yang berjumlah 5 kelas. Namun, yang menjadi sampel dalam penelitian ini yaitu 40 orang siswa dari 5 kelas tersebut, yang masing-masing kelasnya diambil secara acak perkelas 8 0rang. Instrument yang digunakan adalah angket. Teknik analisis yang digunakan adalah menuangkan frekuensi ke dalam bentuk presentase. Hasil penelitian ini menunjukan bahwa Minat belajar siswa dalam mempraktekan pembelajaran penjas di rumah pada masa covid-19 SMAN 1 PASAWAHAN adalah tinggi dengan pertimbangan frekuensi terbanyak berada pada katagori tinggi dengan 13 siswa atau 32,5\%. Minat belajar siswa dalam mempraktekan pembelajaran penjas di rumah pada masa covid-19 siswa SMAN 1 PASAWAHAN yang berkatagori sangat tinggi 4 siswa atau 10\%, tinggi 13 siswa atau 32,5\%, sedang 12 siswa atau $30 \%$, rendah 8 siswa atau $20 \%$, sangat rendah 3 atau $7,5 \%$.
\end{abstract}

Kata Kunci : minat belajar siswa, mempraktekan pembelajaran penjas di rumah

\begin{abstract}
The purpose of this study was conducted to determine student interest in practicing physical education learning at home during the Covid-19 Pandemic Class X at SMAN 1 PASAWAHAN. To answer the formulation of research problems that have been formulated, the author uses a quantitative approach with a survey method. This research was conducted at SMAN 1 PASAWAHAN by taking all class $X$ which amounted to 5 classes. However, the sample in this study were 40 students from the 5 classes, each of whom was randomly drawn per class 8 people. The instrument used was a questionnaire. The analysis technique used is to pour the frequency into a percentage. The results of this study indicate that students' learning interest in practicing physical education learning at home during the covid-19 period of SMAN 1 PASAWAHAN is high with the consideration that the most frequency is in the high category with 13 students or 32.5\%. Students' learning interest in practicing physical education learning at home during the covid-19 period of SMAN 1 PASAWAHAN students were categorized as very high 4 students or $10 \%$, high 13 students or $32.5 \%$, medium 12 students or $30 \%$, low 8 students or $20 \%$, very low 3 or $7.5 \%$.
\end{abstract}

Keywords: student interest in learning, practicing physical education at home

* corresponding author: bellanugraha3@gmail.com

Artikel Info:

Submitted $\quad: \mathbf{2 8} / \mathbf{1 2} / \mathbf{2 0 2 0}$

Revised $\quad: \mathbf{1 8 / 0 2 / 2 0 2 1}$

Accepted $\quad:$ 02/03/2021

Published $\quad: \mathbf{1 7 / 0 5 / 2 0 2 1}$

(4) OPENOAccess

Journal Coaching Education Sports is licensed under a Creatives Commons Attribution 4.0 International License

Copyright $($ C 2021 


\section{A. Pendahuluan}

Seluruh dunia mulai tergoncang dengan adanya virus mematikan asal Wuhan China yaitu Covid-19. Semua elemen kehidupan berubah derastis, kematian dimana-mana hanya karena menghirup virus ini (Parwanto, 2020). Sektor ekonomi yang paling parah menelan ganasnya virus ini tetapi dunia pendidikan pun tak luput oleh ganasnya virus covid-19 (Nasution et al., 2020)

Pendidikan merupakan hal yang tidak dapat dipisahkan dari kehidupan manusia dan sumber daya manusia yang dapat memerlukan wawasan yang sangat luas (Gustiawati \& Julianti, 2018). Pendidikan memegang peran penting untuk membentuk pola pikir, akhlak dan perilaku manusia agar sesuai dengan norma-norma yang ada. Pendidikan adalah proses yang terus menerus dari penyesuaian yang lebih tinggi bagi manusia yang telah berkembang secara fisik dan mental yang bebas dan sadar kepada Tuhan, seperti termanifestasi dalam intelektual, emosional, dan kemanusiaan dari manusia (Inanna, 2018). Sedangkan pendidikan adalah suatu proses atau kegiatan yang diarahkan untuk merubah tabiat (behavior) manusia (Musanna et al., 2017).
Pendidikan jasmani olahraga adalah proses sistematik yang berupa segala kegiatan atau usaha yang dapat mendorong mengembangkan, dan mengembangkan potensi-potensi jasmaniah dan rohaniah seseorang sebagai perorangan atau anggota masyarakat dalam bentuk permainan (Widodo, 2018), perlombaan atau pertandingan, dan kegiatan jasmani yang intensif untuk memperoleh rekreasi, kemenangan, dan prestasi puncak dalam rangka pembentukan manusia indonsia seutuhnya yang berkualitas berdasarkan Pancasila (Dimyati \& Aminah, 2017).

Dalam penelitian ini, peneliti mengangkat masalah tentang minat belajar siswa dalam mempraktekan pembelajaran penjas di rumah pada masa pandemic covid19 pada siswa kelas $\mathrm{X}$ di SMAN 1 PASAWAHAN. Selain itu, peneliti juga ingin mengetahui lebih dalam tentang minat belajar yang ada pada peserta didik.

Dalam kegiatan pelaksanaan pendidikan jasmani di kelas X SMAN 1 PASAWAHAN masih belum mengumpulkan tugas praktek yang diberikan oleh guru, bahkan ada juga beberapa siswa yang tidak sama sekali menghiraukan tugas praktek yang diberikan. Hal ini dimungkinkan karena kurangnya minat dari siswa untuk mengikuti proses 
pembelajaran atau sarana daring di rumah yang tidak memadai.

Berdasarkan pertimbangan diatas, peneliti membuat penelitian yang berjudul "Minat Belajar Siswa Dalam Mempraktekan Pembelajaran Penjas di Rumah di Masa Pandemic Covid-19 Kelas X di SMAN 1 PASAWAHAN", semoga dengan penelitian ini peneliti dapat mengetahui seberapa besar minat siswa dalam mengikuti pembelajaran pendidikan jasmani olahraga dan kesehatan khususnya dalam mempraktekan materi penjas di rumah.

Minat adalah suatu rasa lebih suka dan rasa keterikatan pada suatu hal atau aktivitas, tanpa ada yang menyuruh $(\underline{\mathrm{P}}$, 2019). Minat pada dasarnya adalah penerimaan akan suatu hubungan antara diri sendiri dengan sesuatu diluar diri. Semakin kuat atau dekat hubungan tersebut, maka semakin besar minat (Slameto, 2015).

Menurut (B \& Elizabeth, 1980) mengatakan bahwa, "pada semua usia, minat memainkan peran yang penting dalam kehidupan seseorang dan mempunyai dampak yang besar atas perilaku dan sikap, karena minat menjadi sumber motivasi yang kuat untuk belajar. (Saleh \& Malinta, 2020) Anak yang berminat terhadap sebuah kegiatan, baik permainan maupun pekerjaan, akan berusaha lebih keras untuk belajar dibandingkan dengan anak yang kurang berminat.

Menurut (Pasaribu \& Daulay, 2018) bahwa belajar gerak merupakan suatu rangkaian asosiasi latihan atau pengalaman yang dapat mengubah kemampuan gerak kearah kinerja keterampilan gerak tertentu. Sedangkan menurut (Pasaribu \& Mashuri, 2019) Belajar gerak merupakan suatu pengaturan kembali pola gerak dasar yang mengakibatkan suatu perubahan tingkah laku gerak yang terjadi, sebagai hasil latihan. Menurut (Nurdin et al., 2020) Belajar gerak adalah belajar yang diwujudkan melalui respon-respon/ muskular, yang pada umumnya diekspedisikan dalam gerak tubuh atau bagian tubuh.

Coronavirus merupakan virus yang menyebabkan penyakit mulai dari flu biasa hingga penyakit yang lebih parah. Gejala yang ditemukan sepertidemam, batuk, sesak napas dan kesulitan bernafas (Susilo et al., 2020). Pada kasus yang lebih parah, infeksi dapat menyebabkan pneumonia, sindrom pernapasan akut, gagal ginjal, dan bahkan kematian (Handayani et al., 2020). Kasus positif covid-19 pertama di Indonesia terjadi pada bulan Maret 2020 kemudian beberapa Coronavirus merupakan virus yang 
menyebabkan penyakit mulai dari flu biasa hingga penyakit yang lebih parah (Yuliana, $\underline{2020})$.

\section{B. Metode Penelitian}

Dalam penelitian ini, peneliti menggunakan pendekatan kuantitatif. Metode penelitian yang digunakan dalam penelitian ini adalah survey. Menurut (Sugiyono, 2012) mengungkapkan, "metode survey digunakan untuk mendapatkan data dari tempat tertentu yang alamiah (bukan buatan), tetapi peneliti melakukan perlakuan dalam pengumpulan data, misalnya dengan mengedarkan kuisioner, test, wawancara terstruktur dan sebagainya (perlakuan tidak seperti dalam eksperimen). Dengan kata lain, teknik pengumpulan data secara kuisioner atau berbentuk angket.

Adapun populasi dari penelitian ini adalah seluruh siswa kelas X SMAN 1 PAAWAHAN yaitu, kelas X MIPA 1, X MIPA 2, X MIPA 3, X IIS 1 dan X IIS 2 yang berjumlah 187 siswa yang ada di SMAN 1 PASAWAHAN.

Sampel adalah sebagian atau wakil populasi yang kita akan teliti (Arikunto, 2010). Untuk sekedar ancer-ancer, maka apabila subjeknya kurang dari 100, lebih baik diambil semua sehingga penelitiannya merupakan penelitian populasi. Tetapi, jika jumlah subjeknya besar, dapat diambil antara $10-15 \%$ atau $20-25 \%$ atau lebih. Dalam penelitian ini, peneliti mengambil $22 \%$ dari jumlah populasi yang ada, karena populasi dalam penelitian ini subjeknya lebih dari 100. Dikatakan simple (sederhana) karna pengambilan anggota sampel dari populasi dilakukan secara acak tanpa memperhatikan strata yang ada dalam populasi itu. Jumlah sampel yang digunakan adalah sebanyak 40 orang siswa dari masing masing kelas $\mathrm{X}$. X MIPA $1=8, \mathrm{X}$ MIPA 2= $8, \mathrm{X}$ MIPA $3=8, \mathrm{X}$ IIS $1=8, \mathrm{X}$ IIS $2=8$.

Adapun instrument dalam penelitian ini adalah berupa angket yang akan disebarluaskan dan di ujicobakan terlebih dahulu kepada sekolah yang berbeda yaitu SMAN 1 MANDIRANCAN di Cirebon.

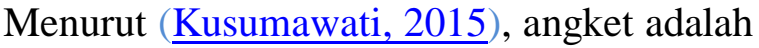
sebuah pernyataan, jawaban yang akan responden isi sudah disediakan oleh peneliti sehingga responden hanya perlu menceklis ataupun memberi silang pada pernyataan yang sesuai dengan keadaan responden.

Adapun tahapan penelitian yang dilakukan dalam penelitian ini dengan cara sebagai berikut:

- Di tetapkan di sekolah tempat penelitian. 
- Ditetapkan sampel siswa siswi kelas SMAN 1 PASAWAHAN yang diambil secara simple random sampling.

- Mempersiapkan tenaga pembantu dan pengawas pelaksanaan penelitian.

- Menjelaskan kepada sampel tentang maksud dan tujuan penelitian.

- Sebelum diadakan penelitian, angket di uji validasi terlebih dahulu di SMAN 1

\section{MANDIRANCAN}

- Hasil tes dan pengukuran selanjutnya dihitung dan dianalisa dengan statistik.

Tabel 1 Norma Penilaian

\begin{tabular}{cll}
\hline NO & Interval & Kategori \\
\hline 1 & $\mathrm{X} \geq \mathrm{M}+1 . \mathrm{SD}$ & Sangat Baik \\
2 & $\mathrm{M} \leq \mathrm{X}<\mathrm{M}+1$. & Baik \\
& $\mathrm{SD}$ & \\
3 & $\mathrm{M}-1 . \mathrm{SD} \leq \mathrm{X}<$ & Kurang Baik \\
& $\mathrm{M}$ & $\begin{array}{l}\text { Sangat Kurang } \\
\text { Baik }\end{array}$ \\
\hline & $\mathrm{M}-1 . \mathrm{SD}>\mathrm{X}$ & \\
\hline
\end{tabular}

\section{Hasil dan Pembahansan}

Tabel 2 Hasil Presentase data keseluruhan

\begin{tabular}{llll}
\hline Interval & Frek & $\begin{array}{l}\text { Presenta } \\
\text { se }\end{array}$ & Katagori \\
\hline $86,279<\mathrm{X}$ & 4 & $10 \%$ & $\begin{array}{l}\text { Sangat } \\
\text { Tinggi }\end{array}$ \\
$76,513<\mathrm{X} \leq 13$ & $32,5 \%$ & $\begin{array}{l}\text { Tinggi } \\
86,279\end{array}$ & Sedang \\
$66,747<\mathrm{X} \leq 12$ & $30 \%$ & Rendah \\
76,513 & & & \\
$56,981<\mathrm{X} \leq 8$ & $20 \%$ & $\begin{array}{l}\text { Sangat } \\
\text { Rendah }\end{array}$ \\
$\mathbf{6 6 , 7 4 7} \leq 56,981$ & 3 & $7,5 \%$ & \\
\hline Total & $\mathbf{4 0}$ & $\mathbf{1 0 0 \%}$ & \\
\hline
\end{tabular}

Dari tabel diatas, dapat diketahui bahwa minat belajar siswa dalam mempraktekan pembelajaran penjas di rumah dimasa covid19 pada siswa kelas X SMAN 1 PASAWAHAN yaitu 4 orang siswa (10\%) mempunyai minat belajar dengan katagori sangat tinggi, 13 orang siswa $(32,5 \%)$ mempunyai minat belajar dengan katagori tinggi, 12 orang siswa (30\%) mempunyai minat belajar dengan katagori sedang, 8 orang siswa (20\%) mempunyai minat belajar dengan katagori rendah, dan 3 orang siswa $(7,5 \%)$ mempunyai minat belajar dengan katagori sangat rendah.

Tabel 3 Hasil Presentase Faktor Intrinsik

\begin{tabular}{llll}
\hline Interval & Frek & Presentase & Katagori \\
\hline $45,8505<\mathrm{X}$ & 5 & $12,5 \%$ & $\begin{array}{l}\text { Sangat } \\
\text { Tinggi }\end{array}$ \\
$39,5835<\mathrm{X} \leq 10$ & $25 \%$ & $\begin{array}{l}\text { Tinggi } \\
45,8505\end{array}$ & Sedang \\
$33,3165<\mathrm{X} \leq 18$ & $45 \%$ & Rendah \\
39,5835 & $10 \%$ & \\
$27,0495<\mathrm{X} \leq 4$ & & $\begin{array}{l}\text { Sangat } \\
\text { Rendah }\end{array}$ \\
$\begin{array}{l}\mathrm{X} \leq 27,3165 \\
\text { Total }\end{array}$ & & $7,5 \%$ & \\
\hline
\end{tabular}

Dari tabel diatas, dapat diketahui faktor intrinsik bahwa minat belajar siswa dalam mempraktekan pembelajaran penjas di rumah dimasa covid-19 pada siswa kelas $\mathrm{X}$ SMAN 1 PASAWAHAN yaitu 5 orang siswa $(12,5 \%)$ mempunyai minat dengan katagori sangat tinggi, 10 orang siswa (25\%) 
mempunyai minat bealajar dengan katagori tinggi, 18 orang siswa (45\%) mempunyai minat bealajar dengan katagori sedang, 4 orang siswa (10\%) mempunyai minat belajar dengan katagori rendah, dan 3 orang siswa $(7,5 \%)$ mempunyai minat belajar dengan katagori sangat rendah.

Tabel 4 Hasil Presentase Perasaan Senang

\begin{tabular}{llll}
\hline \multicolumn{1}{c}{ Interval } & $\begin{array}{l}\text { Fre } \\
\mathbf{k}\end{array}$ & $\begin{array}{l}\text { Presenta } \\
\text { se }\end{array}$ & Katagori \\
\hline $29,388<\mathrm{X}$ & 6 & $15 \%$ & $\begin{array}{l}\text { Sangat } \\
\text { Tinggi }\end{array}$ \\
$25,396<\mathrm{X} \leq 11$ & $27,5 \%$ & $\begin{array}{l}\text { Tinggi } \\
29,388\end{array}$ & \\
$21,404<\mathrm{X} \leq 16$ & $40 \%$ & Sedang \\
25,396 & & & \\
$17,412<\mathrm{X} \leq 5$ & $12,5 \%$ & Rendah \\
21,404 & & $5 \%$ & $\begin{array}{l}\text { Sangat } \\
\text { Rendah }\end{array}$ \\
$\mathrm{X} \leq 17,412$ & 2 & & \\
\hline
\end{tabular}

Dari tabel diatas, dapat diketahui bahwa indikator perasaan senang minat belajar siswa dalam mempraktekan pembelajaran penjas di rumah dimasa covid-19 pada siswa kelas X SMAN 1 PASAWAHAN yaitu 6 orang siswa (15\%) mempunyai minat belajar dengan katagori sangat tinggi, 11 orang siswa $(27,5 \%)$ mempunyai minat bealajar dengan katagori tinggi, 16 orang siswa (40\%) mempunyai minat bealajar dengan katagori sedang, 5 orang siswa $(12,5 \%)$ mempunyai minat belajar dengan katagori rendah, dan 2 orang siswa (5\%) mempunyai minat belajar dengan katagori sangat rendah.

\section{Tabel 5 Hasil Presentase Aktifitas}

\begin{tabular}{|c|c|c|c|}
\hline Interval & Frek & Presentase & Katagori \\
\hline $16,785<X$ & 10 & $25 \%$ & $\begin{array}{l}\text { Sangat } \\
\text { Tinggi }\end{array}$ \\
\hline $\begin{array}{l}14,295<X \leq \\
16,785\end{array}$ & 7 & $17,5 \%$ & Tinggi \\
\hline $\begin{array}{l}11,805<X \leq \\
14,295\end{array}$ & 14 & $35 \%$ & Sedang \\
\hline $\begin{array}{l}9,315<X \leq \\
11,805\end{array}$ & 8 & $20 \%$ & Rendah \\
\hline$X \leq 9,315$ & 1 & $2,5 \%$ & $\begin{array}{l}\text { Sangat } \\
\text { Rendah }\end{array}$ \\
\hline Total & 40 & $100 \%$ & \\
\hline
\end{tabular}

Dari tabel diatas, dapat diketahui bahwa indikator aktivitas minat belajar siswa dalam mempraktekan pembelajaran penjas di rumah dimasa covid-19 pada siswa kelas $\mathrm{X}$ SMAN 1 PASAWAHAN yaitu 10 orang siswa $(25 \%)$ mempunyai minat belajar dengan katagori sangat tinggi, 7 orang siswa $(17,5 \%)$ mempunyai minat bealajar dengan katagori tinggi, 14 orang siswa (35\%) mempunyai minat bealajar dengan katagori sedang, 8 orang siswa (20\%) mempunyai minat belajar dengan katagori rendah, dan 1 orang siswa $(2,5 \%)$ mempunyai minat belajar dengan katagori sangat rendah.

Tabel 6 Hasil Presentase Faktor Ekstrinsik

\begin{tabular}{|c|c|c|c|}
\hline Interval & Frek & Presentase & Katagori \\
\hline $41,8445<X$ & 10 & $25 \%$ & $\begin{array}{l}\text { Sangat } \\
\text { Tinggi }\end{array}$ \\
\hline $\begin{array}{l}37,4015<X \leq \\
41,8445\end{array}$ & 7 & $17,5 \%$ & Tinggi \\
\hline $\begin{array}{l}32,9585<\mathrm{X} \leq \\
37,4015\end{array}$ & 14 & $35 \%$ & Sedang \\
\hline $\begin{array}{l}28,5155<X \leq \\
32,9585\end{array}$ & 5 & $12,5 \%$ & Rendah \\
\hline$X \leq 28,5155$ & 4 & $10 \%$ & $\begin{array}{l}\text { Sangat } \\
\text { Rendah }\end{array}$ \\
\hline Total & 40 & $100 \%$ & \\
\hline
\end{tabular}


Dari tabel diatas, dapat diketahui faktor ekstrinsik minat belajar siswa dalam mempraktekan pembelajaran penjas di rumah dimasa covid-19 pada siswa kelas $\mathrm{X}$ SMAN 1 PASAWAHAN yaitu 10 orang siswa (25\%) mempunyai minat dengan katagori sangat tinggi, 7 orang siswa $(17,5 \%)$ mempunyai minat belajar dengan katagori tinggi, 14 orang siswa (35\%) mempunyai minat bealajar dengan katagori sedang, 5 orang siswa $(12,5 \%)$ mempunyai minat belajar dengan katagori rendah, dan 4 orang siswa (10\%) mempunyai minat belajar dengan katagori sangat rendah.

Tabel 7 Hasil Presentase Peranan Guru

\begin{tabular}{llll}
\hline Interval & Frek & Presentase & Katagori \\
\hline $29,831<\mathrm{X}$ & 15 & $37,5 \%$ & $\begin{array}{l}\text { Sangat } \\
\text { Tinggi }\end{array}$ \\
$26,897<\mathrm{X} \leq 5$ & $12,5 \%$ & Tinggi \\
29,831 & & Sedang \\
$23,963<\mathrm{X} \leq 12$ & $30 \%$ & Rendah \\
26,897 & $10 \%$ & \\
$21,029<\mathrm{X} \leq 4$ & $10 \%$ & $\begin{array}{l}\text { Sangat } \\
\text { Rendah }\end{array}$ \\
23,963 & & \\
$\mathrm{X} \leq 21,029$ & 4 & $100 \%$ & \\
Total & 40 & &
\end{tabular}

Dari tabel diatas, dapat diketahui bahwa indikator peranan guru dari minat belajar siswa dalam mempraktekan pembelajaran penjas di rumah dimasa covid-19 pada siswa kelas X SMAN 1 PASAWAHAN yaitu 15 orang siswa $(37,5 \%)$ mempunyai minat belajar dengan katagori sangat tinggi, 5orang siswa $(12,5 \%)$ mempunyai minat bealajar dengan katagori tinggi, 12orang siswa (30\%) mempunyai minat bealajar dengan katagori sedang, 4 orang siswa (10\%) mempunyai minat belajar dengan katagori rendah, dan 4 orang siswa (10\%) mempunyai minat belajar dengan katagori sangat rendah.

\section{Tabel 8 Hasil Presentase Fasilitas}

\begin{tabular}{|c|c|c|c|}
\hline Interval & Frek & Presentase & Katagori \\
\hline $12,765<X$ & 11 & $27,5 \%$ & $\begin{array}{l}\text { Sangat } \\
\text { Tinggi }\end{array}$ \\
\hline $\begin{array}{l}10,755<X \leq \\
12,765\end{array}$ & 7 & $17,5 \%$ & Tinggi \\
\hline $\begin{array}{l}8,745<\mathrm{X} \leq \\
10,755\end{array}$ & 10 & $25 \%$ & Sedang \\
\hline $\begin{array}{l}6,735<X \leq \\
8,745\end{array}$ & 10 & $25 \%$ & Rendah \\
\hline$X \leq 6,735$ & 2 & $5 \%$ & $\begin{array}{l}\text { Sangat } \\
\text { Rendah }\end{array}$ \\
\hline Total & 40 & $100 \%$ & \\
\hline
\end{tabular}

Dari tabel diatas, dapat diketahui bahwa indikator fasilitas dari minat belajar siswa dalam mempraktekan pembelajaran penjas di rumah dimasa covid-19 pada siswa kelas X SMAN 1 PASAWAHAN yaitu 11 orang siswa $(27,5 \%)$ mempunyai minat belajar dengan katagori sangat tinggi, 7 orang siswa $(17,5 \%)$ mempunyai minat bealajar dengan katagori tinggi, 10 orang siswa (25\%) mempunyai minat bealajar dengan katagori sedang, 10 orang siswa (25\%) mempunyai minat belajar dengan katagori rendah, dan 2 orang siswa (5\%) mempunyai minat belajar dengan katagori sangat rendah. 


\section{Kesimpulan}

Berdasarkan hasil yang hitung melalui statistik, maka dapat diambil kesimpulan bahwa minat belajar siswa dalam mempraktekan pembelajaran penjas di rumah dimasa covid-19 pada siswa kelas $\mathrm{X}$ SMAN 1 Pasawahan adalah tinggi, dengan pertimbangan frekuensi terbanyak berada pada katagori tinggi dengan 13 siswa atau $32,5 \%$.

Secara rinci, sebanyak 4 siswa atau 10\% mempunyai minat "sangat tinggi", 13 siswa atau 32,5\% mempunyai minat "tinggi", 12 siswa atau 30\% mempunyai minat "sedang", 8 siswa atau 20\% mempunyai minat "rendah", 3 siswa atau 7,5\% mempunyai minat "sangat rendah.

\section{Daftar Pustaka}

Arikunto, S. (2010). Prosedur Penelitian Suatu Pendekatan Praktik (Edisi Revisi 2010). In Jakarta: Rineka Cipta (10th Ed.).

B, H., \& Elizabeth. (1980). Psikologi Perkembangan Suatu Pendekatan Sepanjang Rentang Kehidupan Edisi Kelima (Lima) (5th Ed.). Erlangga. Http://Stikesmajapahit.Ac.Id/Opac/Inde x.Php?P=Show_Detail\&Id=2495

Dimyati, A., \& Aminah, A. S. (2017).

Pengaruh Fun Outbound Untuk
Meningkatkan Motivasi Siswa Dalam

Mengikuti Pembelajaran Penjas Pada Siswa Kelas XI Di SMK Yisca Cilamaya Karawang. Seminar Nasional Riset Inovatif, 5, 153-158. Https://Eproceeding.Undiksha.Ac.Id/In dex.Php/Senari/Article/View/931

Gustiawati, R., \& Julianti, R. R. (2018).

Pengaruh Model Pendidikan Gerak (Movement Education) Terhadap Hasil Penilaian Kognitif Dalam Pembelajaran

Pendidikan Jasmani Olahraga Dan Kesehatan. Jurnal Speed (Sport, Physical, 2(November), 44-51. Https://Doi.Org/Https://Doi.Org/10.357 06/Speed.V1i2.1731

Handayani, D., Hadi, D. R., Isbaniah, F.,

Burhan, E., \& Agustin, H. (2020).

Corona Virus Disease 2019. Jurnal

Respirologi Indonesia, 40(2), 119-129.

Http://Jurnalrespirologi.Org/Index.Php/

$\underline{\mathrm{Jri} / \text { Article/View/101 }}$

Inanna. (2018). Peran Pendidikan Dalam

Membangun Karakter Bangsa Yang

Bermoral. JEKPEND: Jurnal Ekonomi

Dan Pendidikan, 1(1), 27-33.

Https://Doi.Org/10.26858/Jekpend.V1i $\underline{1.5057}$

Kusumawati, M. (2015). Penelitian Pendidikan Penjasorkes: Pendidikan Jasmani Olahraga Dan Kesehatan 
(Cet. 1.) (1st Ed.). Alfabeta.

Https://Onesearch.Id/Record/IOS6232.I

$\underline{\text { NLIS000000000009337 }}$

Musanna, A., Wibowo, U. B., \&

Hastutiningsih, A. D. (2017).

Indigenisasi Pendidikan: Rasionalitas

Revitalisasi Praksis Pendidikan Ki

Hadjar Dewantara. Jurnal Pendidikan

Dan Kebudayaan, 2(1), 117-133.

Https://Doi.Org/10.24832/Jpnk.V2i1.5

$\underline{29}$

Nasution, D. A. D., Erlina, E., \& Muda, I. (2020). Dampak Pandemi COVID-19 Terhadap Perekonomian Indonesia. Jurnal Benefita, 5(2), 212-224. Https://Doi.Org/10.22216/Jbe.V5i2.531 $\underline{3}$

Nurdin, A., Perabunita, \& Pasaribu, A. M. N. (2020). Pengaruh Media Audio Visual,Video Terhadap Penguasaan Gerak Dasar “Tendangan” Pencak Silat Pada Anggota Perguruan Cimande

Desa Sukadamai Kecamatan Tanjung Lago Kabupaten Banyuasin. Jurnal Speed (Sport, Physical ..., 3(1). Https://Doi.Org/Https://Doi.Org/10.357 06/Jurnal\%20speed.V3i1.3562

P, A. A. (2019). Pengembangan Minat Belajar Dalam Pembelajaran. Idaarah: Jurnal Manajemen Pendidikan, 3(2), 205-215.
Https://Doi.Org/10.24252/Idaarah.V3i2 .10012

Parwanto, M. (2020). Virus Corona (2019Ncov) Penyebab COVID-19. Jurnal Biomedika Dan Kesehatan, 3(1), 1-2. Https://Doi.Org/10.18051/Jbiomedkes. 2020.V3.1-2

Pasaribu, A. M. N., \& Daulay, D. E. (2018). Pengaruh Permainan Lari Estafet Terhadap Kemampuan Gerak Dasar Motorik Kasar Siswa Kelas 3 Sdn Karet Ii Kabupaten Tangerang. Prestasi, 2(4), 9-14. Https://Doi.Org/Https://Doi.Org/10.241 14/Jp.V2i4.11909

Pasaribu, A. M. N., \& Mashuri, H. (2019). The Role Of Rhythmic Gymnastics For Physical Fitness For Elementary School Students. Jurnal SPORTIF: Jurnal Penelitian Pembelajaran, $5(1$ SEArticle), 89-97. Https://Doi.Org/10.29407/Js_Unpgri.V $\underline{5 i 1.12551}$

Saleh, M. S., \& Malinta, S. S. (2020). Survei Minat Belajar Siswa Dalam Mengikuti Pembelajaran Pendidikan Jasmani Di Smpn 30 Makassar. Kinestetik: Jurnal Ilmiah Pendidikan Jasmani, 4(1), 5562.

Https://Doi.Org/10.33369/Jk.V4i1.103 $\underline{47}$ 
Slameto. (2015). Belajar Dan Faktor-Faktor

Yang Mempengaruhi. Rineka Cipta.

Sugiyono. (2012). Metode Penelitian Kuantitatif Dan R\&D. Alfabeta.

Susilo, A., Rumende, C. M., Pitoyo, C. W., Santoso, W. D., Yulianti, M., Sinto, R., Singh, G., Nainggolan, L., Nelwan, E. J., Khie, L., Widhani, A., Wijaya, E., Wicaksana, B., Maksum, M., Annisa, F., Jasirwan, O. M., Yunihastuti, E., Penanganan, T., New, I., ... Cipto, R. (2020). Coronavirus Disease 2019: Tinjauan Literatur Terkini Coronavirus Disease 2019: Review Of Current Literatures. Jurnal Penyakit Dalam Indonesia, $\quad 7(1), \quad 45-67$. Https://Doi.Org/10.7454/Jpdi.V7i1.415 Widodo, A. (2018). Makna Dan Peran Pendidikan Jasmani Dalam Pembentukan Insan. Jurnal Motion, 9(1), 53-60.

Https://Www.Researchgate.Net/Publica tion/329442726_Makna_Dan_Peran_P endidikan_Jasmani_Dalam_Pembentuk an_Insan_Yang_Melek_Jasmaniahter-

Literasi_Jasmaniahnya

Yuliana. (2020). Coronavirus Diseases (Covid-19): Sebuah Tinjauan Literatur. Wellness And Healthy Magazine, 2(1), 187-192.

Https://Wellness.Journalpress.Id/Welln 